\title{
Uncovering Tax Avoidance at Government Agencies: A Phenomenological Research
}

\author{
Moh. Riskiyadi ${ }^{1}$, Tarjo $^{2 *}$, Alexander Anggono ${ }^{3}$
}

AFFILIATION:

1,2,3 Master of Accounting Program, Universitas Trunojoyo Madura

\section{*CORRESPONDENCE:}

tarjo@trunojoyo.ac.id

THIS ARTICLE IS AVAILABLE IN:

https://ojs.unud.ac.id/index.php/jiab

DOI:

10.24843/JIAB.2022.v17.i01.p02

CITATION:

Riskiyadi, M., Tarjo, Anggono, A. (2022). Uncovering Tax Avoidance at Government Agencies: A

Phenomenological Research. Jurnal IImiah Akuntansi dan Bisnis, 17(1), 22-32.

\section{ARTICLE HISTORY}

Received:

29 November 2020

Revised

23 January 2021

Accepted:

27 January 2021

\begin{abstract}
Interpreting tax avoidance as tax fraud is a very interesting discussion because it depends on the point of view of how to react. This research aims to reveal the essence of tax avoidance on financial management in a government agency. This research used a qualitative method with a transcendental phenomenological approach in a government agency of a district in the Madura region with informants from the parties involved in financial management and supplier partners, and data collection was carried out by interview, observation, and documentation. The research findings reveal the essence of financial management compulsion to do tax evasion compared to committing fraud on state or regional finances managed by a government agency. It is hoped that this research will be able to provide a different perspective regarding the dilemma in financial management in government agencies so that regulations and policies on state or regional financial management can be addressed.
\end{abstract}

Keywords: fraud, tax avoidance, tax evasion, government agencies

\section{Introduction}

Fraud is a major problem in all sectors, both private and public and affects the performance of entities and economic conditions around the world (Ozkul \& Pamukcu, 2013). Fraud is like an iceberg phenomenon, where what appears on the surface is only a small part compared to other parts that are not visible so that fraud becomes a problem that must be overcome because it is not impossible that an entity that seems fine is being undermined by the problem of fraud in it (ACFE, 2020). Fraud in the public sector, especially government agencies in Indonesia is very interesting to discuss because government agencies have the responsibility for accountability of public services to the public. With their role as public servants, the central and regional government agencies must always provide optimal public services, because the budget managed by government agencies is a public budget that should be used for the public interest to achieve a just and prosperous society. The public has the right to always guard the collection and use of public budgets that are managed by government agencies so that any potential fraud that occurs in government agencies is always interesting to discuss and debate in the community. The source of state revenue in the form of taxes collected by government agencies is fully utilized for the benefit of 
the community which is distributed to various other government agencies to support the implementation of public services. The phenomenon of the use of public budgets by government agencies must comply with the provisions of the prevailing laws and regulations, among which these provisions are the imposition of taxes on financial transactions that are borne by state or regional finances.

Based on the Indonesian Fraud Survey Report 2019, the occurrence of fraud was still dominated by corruption (54.4\%), misappropriation assets $(28.9 \%)$, and financial statements fraud $(6.7 \%)$ within the loss rate being corruption (69.9\%), misappropriation assets (20.9\%) and financial statement fraud (9.2\%) (ACFE Indonesia Chapter, 2020). Various studies have stated that fraud has occurred in government agencies in managing state or regional finances, fraud occurs starting from the planning, implementation, and administration stages (Sholihah et al., 2016), wherein budgeting fraud is carried out by exploiting loopholes in legal provisions and weaknesses supervision (Indriani et al., 2019), the modus used by inflating budget submissions (Kamal, 2018), manipulating accountability documents and committing fraud during asset procurement (Sholihah \& Prasetyono, 2016). Fraud that occurs in government agencies was triggered by pressure, opportunities, and reasons for justification from financial managers (Manossoh, 2016), for tactical budget needs (Setiawan, 2019; Setiawan et al., 2013), and to make personal gain (Syahrina et al., 2017).

In addition to fraud in terms of state or regional financial expenditures, fraud from the side of state or regional income is also a major problem that must be resolved immediately (Saxunova \& Szarkova, 2017). Tax Avoidance and tax evasion (tax fraud) affect the government's ability to obtain the revenue needed to increase economic growth and national development (Schonenberg, 2020). The impact of huge losses is due to tax fraud, so it is necessary to mitigate the occurrence of tax fraud in the form of prevention, detection and investigation of tax evasion and evasion with various methods proposed based on research results (Adekoya et al., 2020; Ibadin \& Kemebradikemor, 2020; Vanhoeyveld et al., 2020).

Previous studies have mentioned tax fraud or tax evasion due to compulsion, deliberation, unwillingness, and tax official's aggressiveness (Mangoting et al., 2017), financial pressure (Rus, 2019; Suprapti, 2017). Tax avoidance is influenced by pressure, opportunity, and justification (Lederman, 2019) when connected with the causes of fraud. The research results show that the tax system, service quality, and fraud detection are able to reduce tax fraud (Winarsih, 2018), the intention to commit tax fraud is influenced by subjective norms and perceptions of behavioural control (Hidayatulloh, 2016). Public service integrity minimizes tax fraud (Shafer et al., 2016), the aggressive character of executives in taking risks influencing tax avoidance (Noviari \& Suaryana, 2019). A sense of justice is comparable to the desire to embezzle taxes, but the tax system, good service quality, and detection of fraud reduce the perception of tax evasion (Nurfadila, 2020). Factors that influence tax fraud include tax rates, income levels, poor tax administration, corruption, low tax sanctions, perceptions of the use of tax revenues, tax justice, and taxpayer education level (Ibadin \& Kemebradikemor, 2020). Efforts to prevent tax fraud and tax evasion have been carried out by implementing tax sanctions (Sumuan \& Fidiana, 2020), but tax evasion or avoidance continues to occur. To reduce tax fraud, the level of tax compliance can be improved by providing better service quality to taxpayers including security, comfort, fast service, and law enforcement (Supadmi, 2009), fostering trust, good cooperation, and an excellent service climate (Tjondro et al., 2020) and optimizing reporting tax fraud (Farrar et al., 2019; Widuri et al., 2019). 
Tax avoidance by minimizing the tax burden without violating tax provisions is considered legal action and tax evasion by manipulating tax reports is an illegal activity that is not justified because it violates the provisions of tax regulations (Inkiriwang, 2017). Determination of limits on tax avoidance and tax evasion provides uncertainty (Levi, 2010) so that actors can exploit the provisions of taxation regulations (Scipanov, 2017). Tax avoidance can lead to tax evasion (Perpelea \& Perpelea, 2018). Uncertainty about the limits of allowable and unacceptable tax avoidance that leads to tax evasion is an interesting phenomenon to discuss. The justification for perpetrators of tax evasion can provide motivation for tax fraud or tax evasion.

Based on the previous explanation, fraud in government agencies has occurred and tax avoidance is also rampant, so it is important to conduct research to reveal why tax avoidance occurs in financial management in a government agency and what factors encourage tax avoidance adorn the financial management of government agencies. The experience of informants as financial managers in government agencies combined with observation and documentation is expected to provide an overview of the essence of tax avoidance in financial management. This research is very important to do because of the choice of different viewpoints in analysing and interpreting the essence of tax avoidance in financial management in a government agency.

\section{Research Method}

The research method used to reveal the essence of fraud in government agencies is qualitative methods with a phenomenological approach. The phenomenological method used to reveal the group's life experience of a phenomenon, by describing the similarity of experiences experienced by each individual of the group by reducing the experience of each individual into a phenomenon that occurs into a universal essence (Creswell \& Poth, 2018). The phenomenological approach was chosen because this approach is expected to reveal clearly the experiences of financial managers in government agencies. To obtain a detailed and in-depth picture to reveal the essence of tax avoidance that adorns financial management in a government agency, observations are made continuously in this study, covering the roles and responsibilities of key players in financial management.

The type of transcendental phenomenology chosen in this study is expected to obtain a purer essence to describe tax avoidance in financial management in a government agency studied. Transcendental phenomenology This is done by putting aside the experience of the researcher and optimally taking a new perspective on the phenomenon under study, in this case everything is understood by the researcher as if it was obtained for the first time (Creswell \& Poth, 2018). Transcendental phenomenology procedures are carried out by identifying a financial management phenomenon in government agencies to be studied by classifying informant experiences and collecting data or information from informants who are in charge of managing finances in a government agency that is the object of this research. Furthermore, data analysis is carried out by reducing information to important statements or quotes and incorporating these statements into the research theme. Researchers develop textural descriptions about experiences experienced by informants, followed by the development of a structural description of the informant's experience concerning the situation, condition or context and combines the textural description with the structural description to convey the overall essence of the informant's experience. The procedure used in this study from the beginning of determining the appropriate research method to solve research problems to the stage of presenting the essence of tax avoidance that 


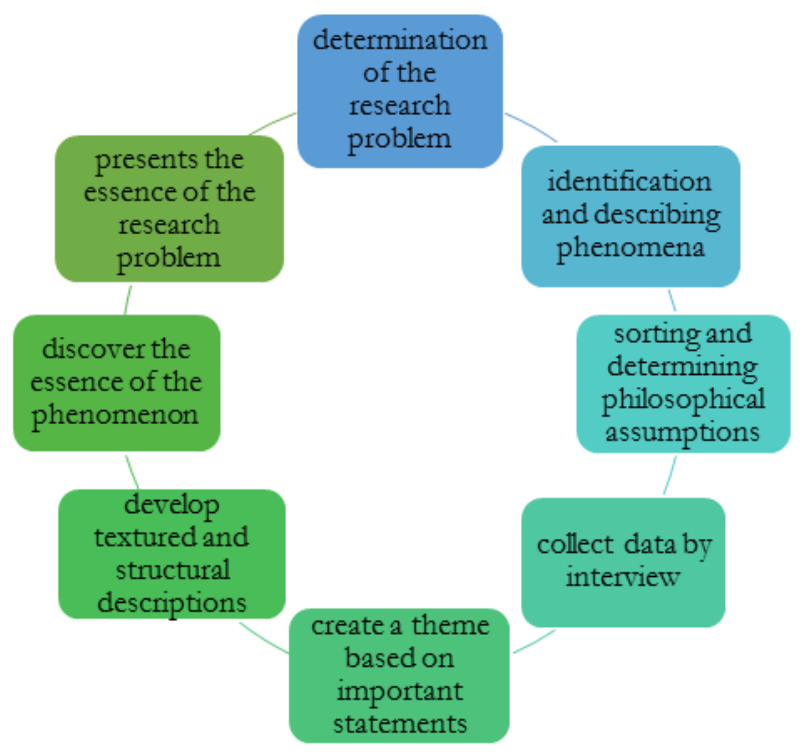

Figure 1. Phenomenology Research Procedure (Creswell \& Poth, 2018)

adorns financial management in a government agency. The phenomenological research procedure used in this study is as shown in Figure 1., which details the disclosure of each stage is presented in the results and discussion.

The study was conducted by interviewing informants, continuous observation over a relatively long period of time about financial management and documentation of all findings obtained during the study. The findings from the results of interviews, observations and documentation become a unit that complements one another. Findings that are interrelated based on the results of interviews, observation and documentation are needed to strengthen the research results.

This research was conducted at a government agency of a district in Madura region that manages state and regional finances. The research location was chosen based on preliminary observations of a government agency that has the potential to do tax avoidance on financial management under its authority. The location is taken as another form of effort to reveal the ways or modes of tax avoidance that occur in local government agencies and the factors that cause tax avoidance. These modes and factors will be explored in depth for financial managers in a government agency that has been determined as the object of research, because financial managers are important figures who know in detail and in-depth the financial management mechanisms that occur in a government agency.

The informants selected in this study are central figures who describe financial management in a government agency that is the object of research, namely financial management officials, financial management staff, and partners, where the experiences of all informants are seen as representing and able to describe the essence of tax avoidance adorn financial management in a government agency. The officials and financial management staff include Riki as the power user of the budget (kuasa pengguna anggaran), Riko as the official commitment maker (pejabat pembuat komitmen), Riza always the official signing the payment order (pejabat penandatangan surat perintah membayar), Rino as expenditure treasurer (bendahara pengeluaran), Rima as financial management staff (staf pengelola keuangan) and Rifa and Riri as shop owners who supplier partners with an agency government which is the object of 
research. The names of the informants as mentioned are not real names, with the aim and purpose of maintaining self-information from informants and maintaining good relations between researchers and informants.

Interviews with informants were conducted not on one occasion, but several different occasions using interview techniques from different points of view, but in the same context. By asking questions at different times and techniques to gather different information, it is hoped that the consistency of the information provided by the informants can be tested. Other interview techniques were also used in this study to obtain information that was truly consistent and described the condition of financial management in a government agency, especially about tax avoidance by confirming statements or information obtained from one informant to another. This method is used to provide an overview of tax avoidance that accompanies the financial management of a government agency.

In addition to the interview method used by researchers, the method of observation was also carried out by researchers over a period of more than one year, in which a relatively long period of time is expected to provide an overview of the financial management of government agencies in one budget year. Observations made include technical planning, use, accountability, and financial reporting which is managed by a government agency. Observation on the performance of financial management, especially regarding taxation, from the time it is planned to the endpoint of reporting, constitutes a single link in the chain that is interconnected with one another. Observations on the assessment of financial management performance have also become the focus of researchers to obtain comprehensive and in-depth information regarding overall financial management in a government agency to be the object of research. Documentation of all interview and observation findings in the form of documents, audio, and video is used for analyse the information captured by the researcher. By documenting the results of the interviews and observations, the analysis of the research results is expected to be structured and able to answer the problems of this study.

To provide the expected research results, the validity of the data or information obtained by the researcher must be tested. Testing the validity of the information is carried out by triangulating data including credibility testing by confirming information between informants and making relatively long and continuous observations. Transferability testing is performed carried out by selecting government agencies that have the potential for fraud in their financial management. Dependability testing is performed that other researchers can perform similarly with the same method. Confirmability testing is performed by examining the results obtained from interviews, observation, and documentation with the research process used, thus the research results obtained come from the research method used by the researcher.

Analysis of data or information obtained by researchers was carried out by performing data reduction, data presentation, verification, and conclusions. Data reduction on information obtained through interviews, observation, and documentation is grouped according to the subject matter or topic discussed, then described in detail to provide a comprehensive picture. The results of the data reduction are presented clearly based on the information provided by the informants and the results of observations and documentation obtained during the study. The presentation of the data is revealed based on the essence captured by the researcher. The disclosure and presentation of the data are continuously verified so that in the end a conclusion can be obtained that answers the research problem. 


\section{Result and Discussion}

The results were obtained from in-depth interviews, continuous and long-lasting observations, and documentation of all phenomena that appear to refer to predetermined research procedures. The research procedure as shown in Figure 1 is the main key to obtaining the results and this discussion. Different procedures provide different angles of means or methods so that different results are obtained, then with different procedures, a different analysis point of view is obtained. This research procedure begins with determining the best research problem using a transcendental phenomenological approach, whereby understanding the general experience or shared experience of several individuals from government agency financial management informants, a description of financial management practices in a government agency understudy can be understood. Next, identify and describe the financial management associated with the tax avoidance phenomenon. Furthermore, it is conducted to sort and determine the philosophical assumptions of transcendental phenomenology by combining objective reality and individual experiences of informants to obtain a description of the informants' experiences about tax avoidance on the financial management of a government agency. The next step is to collect data based on the results of interviews with informants, observation, and documentation regarding the experiences gained, situations or contexts that affect tax avoidance in financial management. Then determine the theme based on the analysis of important statements delivered by informants, observation, and documentation. Followed by the development of descriptions textural and structural based on important statements and themes experienced by each informant (texture description) and describing the context, situations and conditions that influence the experience to occur (structural description) about the experience of tax avoidance so far. The next most important step reveals the essence of the phenomenon of tax avoidance in financial management in government agencies based on combining descriptions textural and structural and presents in the following results and discussion.

Based on the results of observations, interviews, and documentation obtained by researchers, it is mapped into several forms of behaviour fraudulent that arise from pressure, opportunity and justification. The three trigger factors fill the experience space for financial managers of a government agency to do so tax evasion. Here, this phenomenon is revealed to provide an overview of the essence of tax avoidance on financial management in a government agency. The dilemma is felt by the financial manager of a government agency to avoid committing fraud and manipulating expenses by making optimal expenditures to avoid the obligation to collect and deposit taxes. The inevitability that must be faced is a bitter fact for choosing to do tax avoidance.

A forms of tax avoidance on financial transactions managed by the spending treasurer, as a central figure in the financial management of a government agency, Rino gave the following explanation:

“... to avoid tax levies, we usually make purchases in stages, brother, or our transactions split apart, depending on conditions (with a smile), made in such a way so as not to be taxed like that"

How to get around the imposition of taxes some of government agency transactions that are imposed on the state or regional finances that are managed by them, the treasurer of expenditure performs split purchases or services to third parties. Based on observations on the accountability report, it is evident that there are some transactions with a nominal amount that are broken up into some transactions with the 
same partner for different purchase dates or to different partners on the same date. The expenditure treasurer statement is in line with that expressed by Riko as the commitment making official, as the second central figure after the expenditure treasurer, Riko strengthens the statement from the expenditure treasurer, which is as follows:

"... for some activities that we can split apart, we usually split apart because of tax brother"

As an official extension of the power of the budget user with the authority to make commitments or agreements with third parties as partners for purchase or service transactions, the official's commitment maker very well understand that the action taken is also a difficult choice to choose, so avoidance taxes are seen as a preferable measure. Confirmation of different times with different approaches, but with the same intention, the same statement is obtained from the treasurer of expenditure or the official commitment maker. Confirmation and experience deepening of the power of budget users as leaders having absolute power over the budget management of a government agency are exercised to obtain views commensurate with those conveyed by both the expenditure treasurer and the official commitment maker. Riki's question as the power user of the budget reveals a similar experience that he fully understands the conditions faced in managing state or regional finances that he manages about taxation imperative, as follows:

"every transaction, I will definitely get a report from the expenditure treasurer and the official commitment maker, brother, for which transactions are treated like that, so take the best course (shows an optimistic gesture)"

Based on the explanation given by Riki as the holder of financial management control, he is also helpless over the conditions faced in financial management about taxation imperative, so the best choice must be determined, namely avoidance tax is compared to manipulating proof of expenditure. Riza's experience as the official signing the payment order who is tasked with examining the validity of expenditures that burden state or regional finances has a clear understanding of the condition of financial management that he does cannot be separated from the snare of tax avoidance. The following is the experience expressed by Riza based on the following statement:

"... it has often happened, brother, it is commonplace in any government agencies, split apart transactions seems more elegant (ending with a smile)"

The act of breaking up transactions to avoid taxation imperative is a safer and more elegant step according to official signing the payment order, as well as actions to split apart transactions, have often been done and are considered normal for any government agency. The common feeling that occurs and the frequent occurrence of these incidents is to justify tax avoidance as the best form of a solution that must be taken.

Revealing the experiences of financial management officials juxtaposed with the experiences of financial management staff and supplier partners to a government agency in carrying out purchase transactions or services provides an overview of tax avoidance agreement which is known to all parties involved in the financial management of a government agency. The following is the statement of Rima as a financial management staff who also really understands the administration of financial accountability in government agencies:

"the evidence of expenditures that we have recorded is true that some are split apart, usually so that they are not taxed, but for large transactions that cannot be split apart, usually they are just left alone brother..." 
Rima's statement as the financial management staff reinforces the shared experience received by each financial management actor in a government agency. After the interview was conducted at different times with different interview approach methods but with the same intention, the same answers were obtained, so that the statement submitted was deemed sufficient to represent the experience he had experienced. The validity of the data is tested by confirming the main themes that have been obtained from the experiences of each informant in a government agency being studied to Rifa and Riri as owner supplier partners to a government agency in carrying out various financial transactions. The following is an explanation from Rifa:

"... if you have partner here, sometimes the purchase is quite high, the purchase note asks to be split apart brother, he said so as not to be taxed (smiling)"

The partner has also expressed his experience related to supporting evidence of purchases or services provided by split apart a fairly high transaction into several transactions to avoid taxation imperative. Another partner who is also a regular partner of a government agency, Riri as the owner expressed the following statement:

"they often ask for the purchase note to be split apart into how many, but the date is purchase note they ask not to fill it in ...."

Based on the explanation given by Riri as a supplier partner of the government agency who is the object of this research, it provides information that strengthens one another. Opportunities for supplier partners who can be conditioned to separate proof of purchase or services are properly utilized to perpetuate tax avoidance by a government agency.

Based on information from financial managers and supplier partners to government agencies, all agree that tax avoidance is carried out due to pressure on taxation imperative and avoiding fraud is more severe by manipulating evidence of expenditure. The justification for the actions taken is the best solution, it is commonplace and becomes a habit and opportunity to obtain because financial management officials are the core actors in financial management imposed on the state or region and all agree that the action taken is the policy of a government agency. Tax avoidance opportunities can also be obtained because of compromises of financial managers with supplier partners. With a series of statements based on the experiences experienced by each informant, the essence of tax avoidance has occurred in government agencies as a form of avoiding expenditure manipulation which is considered a real fraud. Tax avoidance may still be debatable with regard to actions that occur in a government agency, but the justification for tax avoidance acts is the beginning of another, a larger act of dishonesty so that practical steps in the form of policies and regulations must be addressed in financial management in a government agency this is so that the tax avoidance conditions can be resolved.

Tax avoidance that occurs in a government agency is due to several triggers of opportunity, pressure, and justification. The opportunity that is obtained by the financial managers of a government agency can be created because of the freedom and authority to carry out any desired action, including conditioning purchases or services that are charged to state or regional finances. These opportunities can be created with the strength and power that is owned and the conspiracy to support tax avoidance measures. Pressure provides a strong stimulus to foster an instinct of dishonesty so that pressure on need and pressure of powerlessness is a necessity that must be faced by the financial manager of a government agency that tax avoidance is the best option that can be done. The feeling in the minds of financial managers in justifying their actions erodes 
feelings of regret for dishonesty by the financial managers of a government agency. The justification that there is no other best option to choose apart from tax avoidance and is a common thing in every government agency serves as a reinforcing shield for all actions taken by the financial managers of a government agency. In essence, every human being has a feeling of guilt every time he makes mistakes and dishonesty so that dishonesty actually appears to be action after losing a sense of justification that also arises from every human being the financial manager of a government agency. Based on the natural sense of every human being, a study and analysis is carried out to what extent fear, regret and justification of an action affect the decision to undertake tax evasion.

\section{Conclusion}

Fraud is a necessity that cannot be avoided by an entity, the difference is the size of the act of fraud and the impact it causes. Government agencies have become common occurrence for fraud due to several main factors in the form of perceived pressure, opportunities obtained, and the justification for committing fraud. With a qualitative approach to transcendental phenomenology, this research was conducted to obtain a natural and in-depth essence of tax avoidance that adorns the financial management of a government agency by putting aside the knowledge and experience of researchers.

The apparent essence of tax avoidance that adorns financial management in a government agency is a dilemma to choose tax avoidance as the best form of choice among other options in the form of expenditure manipulation which is considered a real act of fraud. Meanwhile, tax avoidance can be considered as an act that does not violate the provisions of taxation regulations, although it is still a matter of debate to what extent tax avoidance is not categorized as tax fraud. The triggering factors for tax avoidance in the form of pressure, opportunity and justification cannot be separated from conditions that occur in financial management in a government agency, where this is following the theory of triangle fraud.

This research is limited to the triangulation of data used, where confirmation of tax avoidance is only carried out on regular supplier partners of a government agency. Thus, it is a necessary confirmation to the tax service office regarding regulations and their implementation concerning taxation. Suggestions for further research need to do data triangulation involving tax service offices with the same or different research methods such as ethnography or case studies by further elaborating on the causes of tax avoidance or tax evasion.

\section{References}

ACFE. (2020). Report to the Nations on Occupational Fraud and Abuse: 2020 Global Fraud Study. In Association of Certified Fraud Examiners (ACFE).

ACFE Indonesia Chapter. (2020). Survei Fraud Indonesia 2019. In Association of Certified Fraud Examiners (ACFE) Indonesia Chapter.

Adekoya, A. A., Oyebamiji, T. A., \& Lawal, A. B. (2020). Forensic Accounting, Tax Fraud and Tax Evasion in Nigeria - Review of Literatures and Matter for Policy Consideration. International Journal of Emerging Trends in Social Sciences, 9(1), 21-28. https://doi.org/10.20448/2001.91.21.28

Creswell, J., \& Poth, C. (2018). Qualitative Inguiry Research Design: Choosing Among Five Approaches. In SAGE Publications (Vol. 53, Issue 9).

Farrar, J., Hausserman, C., \& Rennie, M. (2019). The Influence of Revenge and Financial Rewards on Tax Fraud Reporting Intentions. Journal of Economic Psychology, 71, 
102-116. https://doi.org/10.1016/j.joep.2018.10.005

Hidayatulloh, A. (2016). Faktor-Faktor Yang Mendorong Wajib Pajak Pribadi Untuk Menggelapkan Pajak. Optimum: Jurnal Ekonomi Dan Pembangunan, 6(2), 189-200. https://doi.org/10.12928/optimum.v6i2.7879

Ibadin, P. O., \& Kemebradikemor, E. (2020). Tax Fraud in Nigeria: A Review of Causal Factors. Journal of Taxation and Economic Development, 19(1), 64-80.

Indriani, N., Alim, M. N., \& Haryadi, B. (2019). The Fraud Portrait in Budget Planning by the Regional Government Apparatus. Journal of Economics, Business, and Accountancy Ventura, 22(1), 115-122. https://doi.org/10.14414/jebav.v22i1.1374

Inkiriwang, K. G. (2017). Perspektif Hukum Terhadap Upaya Penghindaran Pajak oleh Suatu Badan Usaha. Lex Et Societatis, 5(4), 13-18.

Kamal, M. (2018). Penilaian Likelihood Risiko Fraud dalam Manajemen Pemerintah. Jurnal Liquidity, 7(1), 27-32. https://doi.org/10.32546/lq.v7i1.176

Lederman, L. (2019). The Fraud Triangle and Tax Evasion. SSRN Electronic Journal, 3, 151. https://doi.org/10.2139/ssrn.3339558

Levi, M. (2010). Serious Tax Fraud and Noncompliance. Criminology \& Public Policy, 9(3), 493-513. https://doi.org/10.1111/j.1745-9133.2010.00645.x

Mangoting, Y., Sukoharsono, E. G., Rosidi, \& Nurkholis. (2017). Menguak Dimensi Kecurangan Pajak. Jurnal Akuntansi Multiparadigma, 8(2), 274-290. https://doi.org/10.18202/jamal.2017.08.7054

Manossoh, H. (2016). Faktor-Faktor Penyebab Terjadinya Fraud pada Pemerintah di Provinsi Sulawesi Utara. Jurnal EMBA, 4(1), 484-495.

https://doi.org/10.35794/emba.v4i1.11649

Noviari, \& Suaryana. (2019). Mampukah Tata Kelola Perusahaan yang Baik Megurangi Penghindaran Pajak? Jurnal Ilmiah Akuntansi Dan Bisinis, 14(2), 265-275. https://doi.org/10.24843/JIAB.2019.v14.i02.p11

Nurfadila. (2020). Pengaruh Keadilan, Sistem Perpajakan, Kualitas Pelayanan, dan Terdeteksinya Kecurangan Terhadap Penggelapan Pajak Pada Kantor Pelayanan Pajak Madya Makassar. Celebes Equilibrum Journal, 1(2), 44-53.

Ozkul, F. U., \& Pamukcu, A. (2013). Fraud Detection and Forensic Accounting. Emerging Fraud: Fraud Cases from Emerging Economies, 1-185. https://doi.org/10.1007/978-3-642-20826-3

Perpelea, S. G., \& Perpelea, M. O. (2018). The Carousel of Tax Fraud. The Carousel of Tax Fraud, 18(20), 131-137.

Rus, M. I. (2019). Tax Evasion Vs. Fiscal Fraud. Fiat lustitia, O(2), 144-148.

Saxunova, D., \& Szarkova, R. (2017). Tax Management Hierarchy - Tax Fraud and a Fraudster. Management International Conference, 633-644.

http://www.hippocampus.si/ISBN/978-961-7023-71-8/236.pdf

Schonenberg, I. (2020). Intelligent Tax Fraud Detection. Bachelor Thesis Economie \& Informatica Tilburg University.

Scipanov, M. (2017). Tax Fraud. International Scientific Conference "Strategies XXI," 21, 424.

Setiawan, A. R. (2019). "Malo" dan Penegakan Karakter Kejujuran: Tafsir Budaya(wan) Madura atas "Sisi Gelap" Pengelolaan Keuangan Daerah. Jurnal Ilmiah Akuntansi Dan Bisnis, 14(2), 251-264. https://doi.org/10.24843/JIAB.2019.v14.i02.p10

Setiawan, A. R., Irianto, G., \& Achsin, M. (2013). System-Driven (un) Fraud: Tafsir Aparatur Terhadap "Sisi Gelap" Pengelolaan Keuangan Daerah. Jurnal Akuntansi Multiparadigma (JAMAL), 4(April), 85-100.

http://dx.doi.org/10.18202/jamal.2013.04.7184 
Shafer, W. E., Simmons, R. S., \& Yip, R. W. Y. (2016). Social Responsibility, Professional Commitment and Tax Fraud. Accounting, Auditing \& Accountability Journal, 29(1), 1-31. https://doi.org/10.1108/AAAJ-03-2014-1620

Sholihah, S., Alim, M. N., \& Musyarofah, S. (2016). Memotret Pola Fraud pada Rincian Objek Belanja yang Menjadi Temuan BPK. Journal of Auditing, Finance, and Forensic Accounting (JAFFA), 04(2), 101-110. https://doi.org/10.21107/jaffa.v4i2.2783

Sholihah, S., \& Prasetyono. (2016). Fraud Pelaporan Keuangan Sektor Publik. Journal of Auditing, Finance, and Forensic Accounting (JAFFA), 04(1), 53-61. https://doi.org/10.21107/jaffa.v4i1.1882

Sumuan, C. F., \& Fidiana, F. (2020). Tax Sanctions from the Authority Perspective. Jurnal IImiah Akuntansi Dan Bisnis, 15(1), 107-118. https://doi.org/10.24843/jiab.2020.v15.i01.p10

Supadmi, N. L. (2009). Meningkatkan Kepatuhan Wajib Pajak Melalui Kualitas Pelayanan. Jurnal Ilmiah Akuntansi Dan Bisnis, 4(2), 1-14.

Suprapti, E. (2017). Pengaruh Tekanan Keuangan Terhadap Penghindaran Pajak. Jurnal Reviu Akuntansi Dan Keuangan, 7(2), 1013. https://doi.org/10.22219/jrak.v7i2.15

Syahrina, D., Irianto, G., \& Prihatiningtyas, Y. W. (2017). Budaya Cari Untung Sebagai Pemicu Terjadinya Fraud: Sebuah Studi Etnografi. Jurnal Akuntansi Dan Pendidikan (Assets), 6(1), 73-84. http://doi.org/10.25273/jap.v6i1.1294

Tjondro, E., Patuli, L., Andrianto, R., \& Julitha, D. (2020). Tax Authority Versus Peer Communication: The Influence of Trust, Service Climate, and Voluntary Cooperation. Jurnal Ilmiah Akuntansi Dan Bisnis, 15(1), 61-74. https://doi.org/10.24843/jiab.2020.v15.i01.p06

Vanhoeyveld, J., Martens, D., \& Peeters, B. (2020). Value-Added Tax Fraud Detection with Scalable Anomaly Detection Techniques. Applied Soft Computing Journal, 86(105895), 1-20. https://doi.org/10.1016/j.asoc.2019.105895

Widuri, R., Jevera, I., \& Zerlinda, J. (2019). Tax Fraud Reporting: The Effect of Envious Motive and Financial Reward. Advances in Economics, Business and Management Research, 103, 89-94. https://doi.org/10.2991/teams-19.2019.13

Winarsih, E. (2018). Pengaruh Sistem Perpajakan, Kualitas Pelayanan dan Terdeteksinya Kecurangan Terhadap Penggelapan Pajak. Jurnal IImiah Mahasiswa Akuntansi, 1(1), 55-69. https://doi.org/10.33096/atestasi.v1i1.55 